\title{
Exploratory study on the correlation between 14 lung cancer-related gene expression and specific clinical characteristics of NSCLC patients
}

\author{
YI HAN $^{1 *}$, GUO LI $^{2 *}$, CHONGYU SU $^{1}, \mathrm{HUA} \mathrm{REN}^{3}$, XIANGYANG CHU $^{2}$, QIUYUE ZHAO ${ }^{1}$, \\ YANJUN ZHU ${ }^{4}$, ZITONG WANG ${ }^{1}$, BIN HU ${ }^{5}$, GUANGYU AN ${ }^{5}$, JINGBO KANG ${ }^{6}$, WEI WANG ${ }^{6}$, \\ DAPING YU ${ }^{1}$, XIAOYUN SONG ${ }^{1}$, NING XIAO $^{1}$, YUNSONG LI $^{1}, \mathrm{XIA} \mathrm{LI}^{7}$, \\ HUIYI YANG ${ }^{7}$, GANG YU $^{7}$ and ZHIDONG LIU ${ }^{1}$ \\ ${ }^{1}$ Department of Thoracic Surgery, Beijing Chest Hospital, Beijing 101149; ${ }^{2}$ Department of Thoracic Surgery, \\ Chinese PLA General Hospital, Beijing 100853; ${ }^{3}$ General Hospital of the Chinese Armed Police Forces, Beijing 100039; \\ ${ }^{4}$ General Hospital of the Air Force, PLA, Beijing 100142; ${ }^{5}$ Beijing Chao-Yang Hospital, Capital Medical University, \\ Beijing 100020; ${ }^{6}$ Navy General Hospital, Beijing 100048; ${ }^{7}$ SurExam Bio-Tech Co. Ltd., \\ Guangzhou Technology Innovation Base, Science City, Guangzhou 510663, P.R. China
}

Received December 14, 2012; Accepted May 15, 2013

DOI: $10.3892 / \mathrm{mco} .2013 .153$

\begin{abstract}
Personalized medicine has become essential in the treatment of lung cancer. However, the lung cancer-related gene expression profiles in non-small cell lung cancer (NSCLC) patients have not been elucidated. In this study, the correlation between gene expression profiles and clinicopathological characteristics was investigated in NSCLC patients. A total of 95 patients were enrolled in this study. The mRNA expression levels of 14 genes were assessed by multiplex branched DNA liquidchip (MBL) technology and data on 9 clinicopathological characteristics of patients were collected simultaneously. The correlation between gene expression and
\end{abstract}

Correspondence to: Professor Zhidong Liu, Department of Thoracic Surgery, Beijing Chest Hospital, Capital Medical University, 97 North MaChang Road, Tongzhou, Beijing 101149, P.R. China

E-mail: hanyee_bj@sina.cn

*Contributed equally

Abbreviations: ERCC1, excision repair cross-complementing rodent repair deficiency, complementation group 1; BRCA1, breast cancer 1; TYMS, thymidylate synthetase; RRM1, ribonucleotide reductase M1; TUBB3, tubulin, $\beta 3$ class III; STMN1, stathmin 1; TOP2A, topoisomerase II $\alpha$; EGFR, epidermal growth factor receptor; VEGFR1, vascular endothelial growth factor receptor 1; HER2, human epidermal growth factor receptor 2; IGF1R, insulin-like growth factor 1 receptor; PDGFR, platelet-derived growth factor receptor

Key words: non-small cell lung cancer, clinicopathological, expression of genes clinicopathological characteristics was investigated. Out of the 9 clinicopathological parameters, 6 were associated with several of the 14 genes analyzed. Patient gender was associated with TYMS and TOP2A. Clinical stage was associated with VEGFR2, KIT and HER2. There was weak correlation between primary tumor size of $\leq 3 \mathrm{~cm}$ and the expression level of KIT. The mRNA expression levels of VEGFR2 and HER2 correlated with distant metastasis. BRCA1, TYMS, TOP $2 A$ and HER2 were associated with histological type. Smoking correlated with higher expression levels of BRCA1, TYMS and $T O P 2 A$ and lower expression levels of $P D G F R \beta$. The results were suggestive of correlation between the clinicopathological parameters of the NSCLC patients and the mRNA expression levels of certain lung cancer-related genes, including BRCA1, TYMS, TOP2A, PDGFR $\beta$, VEGFR2, KIT and HER2.

\section{Introduction}

Lung cancer is a leading cause of mortality worldwide and non small-cell lung cancer (NSCLC) constitutes $80 \%$ of all lung cancer cases $(1,2)$. NSCLC is commonly diagnosed at an advanced stage, which leads to a poor prognosis (3). More effective individualized cancer therapies are necessary to achieve the best possible outcome for each patient, which is the ultimate goal of personalized medicine (4). Studies were previoiusly conducted to identify genes related to treatment responses of NSCLC, breast, colorectal and other types of cancer exhibiting a high prevalence (5-7). The treatment of NSCLC may be significantly improved with improved understanding of the molecular basis of the disease and innovative laboratory technology. In this study, 14 lung cancer-related genes were selected, based on previous studies, and we attempted to identify the association between the genes mRNA expression levels and specific clinicopathological characteristics of NSCLC patients. This study may help develop novel 
ways of selection of the appropriate treatment strategy for patients with NSCLC using molecular diagnostic tools.

\section{Materials and methods}

Patient and specimen collection. A total of 142 Chinese NSCLC patients who underwent surgery at Beijing Chest Hospital, Capital Medical University, between May, 2010 and December, 2011 were screened. Of these 142 patients, 95 were enrolled into analysis according to rank randomization tests and SPSS software version 18.0 (SPSS Inc., Chicago, IL, USA) was used to randomly assign the observations. The surgery specimens were collected for detection of mRNA expression. Detection of the following genes was performed in this study: ERCCl, BRCA1, TYMS, RRM1, TUBB3, STMN1, TOP 2A, EGFR, PDGFR $\beta, V E G F R 1, V E G F R 2$, KIT, HER2 and IGFIR. Subsequently, 9 patient clinicopathological parameters were assessed, including gender, age, clinical stage, primary tumor size, nodal status, distant metastasis status, histological type, differentiation and smoking history.

Detection of mRNA expression levels. A novel multiplex branched DNA liquidchip (MBL) technology, which integrates the branched DNA (bDNA) and liquidchip technology, was developed for quantitative measurement of the gene mRNA levels in the formalin-fixed paraffin-embedded (FFPE) slides. MBL is a non-PCR-based technology. It is a nucleic acid sandwich hybridization platform in which targets are captured through cooperative hybridization of multiple probes and then conjunct with a fluorescence signal amplification system $(8,9)$.

The MBL method was as follows: Sample pretreatment: The FFPE tissue samples were homogenized in a mixture of homogenizing solution at $65^{\circ} \mathrm{C}$ for $2 \mathrm{~h}$. The homogenate was centrifuged to remove residual paraffin and debris and the supernatant was transferred to a fresh centrifuge tube. The homogenate $(40 \mu \mathrm{l})$ was added to each well of a 96-well plate containing the reagents: $18.5 \mu 1 \mathrm{RNase}-$ free water, $33.3 \mu 1$ lysozyme solution, $2 \mu 1$ blocking reagent, $1 \mu 1$ capture beads and $5 \mu 1$ target gene-specific pretreatment probe set. the 96-well plate was sealed and incubated at $54^{\circ} \mathrm{C}$ for $18 \mathrm{~h}$ on a shaker at $314 \mathrm{x}$ g. The hybridization mixture was then transferred to a filtered 96-well plate. The unbound RNA and other debris in the wells were removed by washing three times with $250 \mu \mathrm{l}$ wash buffer under a magnetic adsorption system.

Signals for bound target mRNA were developed using the following steps: incubation in $100 \mu \mathrm{l}$ preamplifier solution at $50^{\circ} \mathrm{C}$ for $1 \mathrm{~h}$; washing twice with $200 \mu \mathrm{l}$ wash buffer; incubation in $100 \mu \mathrm{l}$ amplifier solution at $50^{\circ} \mathrm{C}$ for $1 \mathrm{~h}$; washing twice with $200 \mu \mathrm{l}$ wash buffer; incubation in $100 \mu \mathrm{l}$ labeled probe at $50^{\circ} \mathrm{C}$ for $1 \mathrm{~h}$; and washing twice with $200 \mu \mathrm{l}$ wash buffer. The samples were then developed with $100 \mu 1$ streptavidin-phycoerythrin solution at $25^{\circ} \mathrm{C}$ for $30 \mathrm{~min}$. The fluorescence value of each sample was analyzed using the Luminex 200 system (Luminex, Austin, TX, USA).

This MBL platform is currently used in China for clinical pharmacogenomic diagnosis in personalized chemotherapy for NSCLC in order to measure mRNA levels of ERCC1, $B R C A 1, T U B B 3$ and STMN1, as well as TYMS, RRM1, TOP2A, EGFR, PDGFR, VEGFR1, VEGFR2, KIT, HER2 and IGFIR.
Table I. Characteristics of NSCLC patients.

\begin{tabular}{lc}
\hline Characteristics & No. (\%) \\
\hline Gender & \\
Male & $53(55.8)$ \\
Female & $42(44.2)$ \\
Age (years) & \\
$<65$ & $61(64.2)$ \\
$\geq 65$ & $34(35.8)$ \\
Stage & \\
I & $20(21.1)$ \\
II & $18(18.9)$ \\
III & $30(31.6)$ \\
IV & $23(24.2)$ \\
Undetermined & $4(4.2)$
\end{tabular}

Primary tumor

$\mathrm{T} 1$

$24(25.3)$

$\mathrm{T} 2$

$37(38.9)$

$16(16.8)$

T3

$12(12.6)$

Undetermined

$6(6.3)$

Lymph node status

NO

$31(32.6)$

N1

$17(17.9)$

$\mathrm{N} 2$

$33(34.7)$

N3

$8(8.4)$

Undetermined

$6(6.3)$

Distant metastasis

M0

68 (71.6)

M1

$21(22.1)$

$6(6.3)$

Undetermined

$66(69.5)$

$28(29.5)$

Non-adenocarcinoma

37 (38.9)

$30(31.6)$

$15(15.8)$

$13(13.7)$

Undetermined

$42(44.2)$

49 (51.6)

4 (4.2)

NSCLC, non-small cell lung cancer.

Statistical analysis. SPSS statistical software version 18.0 was used to analyze data in this study. For each gene, we divided the detection values into two groups according to the median value of the 95 patients. Detection values above the median constituted the high-level group, whereas values below the median constituted the low-level group. The $\chi^{2}$ test was used to assess the association between gene expression grades and each of the clinicopathological characteristics. The 
Table II. Expression levels of genes in 95 NSCLC tumors.

\begin{tabular}{|c|c|c|c|c|}
\hline \multirow[b]{2}{*}{ Gene } & \multirow[b]{2}{*}{ Median value } & \multicolumn{2}{|c|}{ Quartile } & \multirow{2}{*}{$\begin{array}{c}\text { Interquartile } \\
\text { range }\left(Q_{U}-Q_{L}\right)\end{array}$} \\
\hline & & $25 \%$ & $75 \%$ & \\
\hline ERCCl & 0.621 & 0.526 & 0.879 & 0.353 \\
\hline$B R C A 1$ & 0.064 & 0.038 & 0.109 & 0.071 \\
\hline$T Y M S$ & 0.107 & 0.059 & 0.205 & 0.146 \\
\hline$R R M 1$ & 0.237 & 0.177 & 0.340 & 0.163 \\
\hline TUBB3 & 0.105 & 0.054 & 0.297 & 0.243 \\
\hline STMN1 & 1.500 & 1.096 & 2.637 & 1.541 \\
\hline$T O P 2 A$ & 0.160 & 0.082 & 0.348 & 0.266 \\
\hline$E G F R$ & 0.507 & 0.285 & 0.957 & 0.672 \\
\hline$P D G F R$ & 0.123 & 0.075 & 0.196 & 0.121 \\
\hline VEGFRI & 0.067 & 0.048 & 0.109 & 0.061 \\
\hline VEGFR2 & 0.202 & 0.115 & 0.327 & 0.212 \\
\hline$K I T$ & 0.179 & 0.091 & 0.309 & 0.218 \\
\hline HER2 & 0.294 & 0.154 & 0.466 & 0.312 \\
\hline$I G F I R$ & 0.189 & 0.118 & 0.289 & 0.171 \\
\hline
\end{tabular}

NSCLC, non-small cell lung cancer; $E R C C 1$, excision repair cross-complementing rodent repair deficiency, complementation group 1; BRCA1, breast cancer 1; TYMS, thymidylate synthetase; RRM1, ribonucleotide reductase M1; TUBB3, tubulin, $\beta 3$ class III; STMN1, stathmin 1; TOP2A, topoisomerase II $\alpha$; EGFR, epidermal growth factor receptor; PDGFR, platelet-derived growth factor receptor; VEGFRl, vascular endothelial growth factor receptor 1; HER2, human epidermal growth factor receptor 2; IGFIR, insulin-like growth factor 1 receptor; $\mathrm{Q}_{\mathrm{U}}$, upper quartile; $\mathrm{Q}_{\mathrm{L}}$, lower quartile.

relevance of the two factors was revealed as the Spearman's rank correlation and the correlation intensity was described as the correlation coefficient. All tests were two-sided and $\mathrm{P}<0.05$ was considered to indicate a statistically significant difference.

\section{Results}

Patient characteristics. Of the 95 patients, 53 were males and 42 females. Sixty-one patients were $<65$ years and 34 were $>65$ years old. A total of 20,18, 30 and 23 patients had clinical stage I, II, III and IV disease, respectively, whereas in 4 patients the clinical stage was undetermined. Distant metastasis was present in 21 patients, absent in 68 and undetermined in 6. Sixty-six patients had adenocarcinoma, 28 had non-adenocarcinoma and information on 1 patient was not available. The degree of differentiation was low, moderate, high and undetermined in 37, 30, 15 and 13 patients, respectively. Forty-nine patients were smokers, 42 had never been smokers and the smoking status of 4 was undetermined. The patient characteristics are listed in Table I.

Gene expression profiles. The median mRNA expression level of ERCCl was 0.621 (range, 0.526-0.879) in the 95 patients. The $25 \%$ of the 95 detection values was 0.526 , whereas the 75\% was 0.879 . The $\mathrm{Q}_{\mathrm{U}}-\mathrm{Q}_{\mathrm{L}}$ of the ERCC1 mRNA expression was 0.353 . The expression levels of the 14 genes are presented in detail in Table II.

Correlation of gene expression levels and patient clinicopathological characteristics. Of the 14 genes, 6 (ERCC1, RRM1, TUBB3, EGFR, VEGFRI and IGFIR) exhibited no association with the nine clinicopathological characteristics.
Furthermore, 3 patient characteristics (age, nodal status and differentiation) were not associated with any of the 14 genes assessed in this study.

TYMS and TOP $2 A$ correlated with gender. Male patients exhibited higher expression levels of TYMS $(\mathrm{P}=0.005)$ and TOP $2 A(\mathrm{P}=0.017)$. Patients in the advanced stages of the disease were associated with higher levels of VEGFR2 $(\mathrm{P}=0.028)$ and lower levels of KIT $(\mathrm{P}=0.016)$. In primary tumors, higher levels of $K I T(\mathrm{P}=0.016)$ were observed in patients with tumor size $\leq 3 \mathrm{~cm}$ (Table III). Among all NSCLC patients, $35 \%$ presented with negative nodal status. The expression levels of VEGFR2 and HER2 exhibited a direct correlation with distant metastasis. The correlation coefficients of VEGFR2 and HER2 were $0.285(\mathrm{P}=0.007)$ and 0.217 $(\mathrm{P}=0.041)$, respectively (Table IV).

The expression levels of BRCA1,TYMS, TOP $2 A$ and HER2 were associated with histological type and the expression levels of BRCA1, TYMS and TOP $2 A$ were different between adenocarcinoma and non-adenocarcinoma patients (the correlation coefficients of the three genes were $0.419, \mathrm{P}=0.000$; $0.293, \mathrm{P}=0.004$; and $0.247, \mathrm{P}=0.017$, respectively). There was a marked correlation between the expression levels of $B R C A 1$ and histological type. However, the expression levels of HER2 were inversely associated with histological type. The correlation coefficient was $0.265(\mathrm{P}=0.010)$ (Table IV). This finding indicates that patients with adenocarcinoma exhibit low expression levels of HER2.

Similarly, BRCA1, TYMS, TOP $2 A$ and $P D G F R \beta$ were associated with smoking status $(\mathrm{P}=0.009, \mathrm{P}=0.015, \mathrm{P}=0.004$ and $\mathrm{P}=0.026$, respectively). Smoking patients tended to exhibit higher expression levels of BRCA1, TYMS and TOP2A (the correlation coefficients were $0.275, \mathrm{P}=0.008 ; 0.254, \mathrm{P}=0.015$; 
Table III. Relationships between mRNA levels and clinical characteristics.

\begin{tabular}{lccccccccc}
\hline Characteristic & Statistics & BRCA1 & TYMS & STMN1 & TOP2A & PDGFR & VEGFR2 & KIT & HER2 \\
\hline Gender & $\chi^{2}$ & 3.042 & 7.846 & 0.255 & 5.702 & 1.318 & 0.255 & 1.771 & 0.008 \\
& P-value & 0.081 & 0.005 & 0.614 & 0.017 & 0.251 & 0.614 & 0.183 & 0.927 \\
Age (years) & $\chi^{2}$ & 0.124 & 0.006 & 0.006 & 0.006 & 3.176 & 0.006 & 3.200 & 0.608 \\
Stage & P-value & 0.725 & 0.939 & 0.939 & 0.939 & 0.075 & 0.939 & 0.074 & 0.436 \\
& $\chi^{2}$ & 1.455 & 1.769 & 4.989 & 3.949 & 0.626 & 9.081 & 10.277 & 8.388 \\
Primary tumor & P-value & 0.693 & 0.622 & 0.173 & 0.267 & 0.890 & 0.028 & 0.016 & 0.039 \\
& $\chi^{2}$ & 4.832 & 1.482 & 4.314 & 3.665 & 3.829 & 6.149 & 10.267 & 1.799 \\
Lymph nodes & P-value & 0.185 & 0.686 & 0.230 & 0.300 & 0.281 & 0.105 & 0.016 & 0.615 \\
& $\chi^{2}$ & 3.692 & 7.394 & 0.839 & 5.162 & 3.622 & 0.353 & 1.385 & 1.073 \\
Distant metastasis & P-value & 0.297 & 0.060 & 0.840 & 0.160 & 0.305 & 0.950 & 0.709 & 0.784 \\
& $\chi^{2}$ & 0.036 & 0.095 & 0.036 & 0.653 & 0.328 & 7.222 & 1.709 & 4.183 \\
Histological type & P-value & 0.849 & 0.758 & 0.849 & 0.419 & 0.567 & 0.007 & 0.191 & 0.041 \\
& $\chi^{2}$ & 16.481 & 8.074 & 1.831 & 5.713 & 1.075 & 1.075 & 3.255 & 6.618 \\
Differentiation & P-value & 0.000 & 0.004 & 0.176 & 0.017 & 0.300 & 0.300 & 0.071 & 0.010 \\
\multirow{2}{*}{ Smoking history } & $\chi^{2}$ & 1.462 & 5.942 & 5.544 & 0.795 & 0.443 & 0.443 & 4.043 & 5.427 \\
& P-value & 0.481 & 0.051 & 0.063 & 0.672 & 0.801 & 0.801 & 0.132 & 0.066 \\
& $\chi^{2}$ & 6.867 & 5.888 & 0.268 & 8.106 & 4.988 & 0.507 & 1.357 & 0.085 \\
& P-value & 0.009 & 0.015 & 0.605 & 0.004 & 0.026 & 0.476 & 0.244 & 0.771 \\
\hline
\end{tabular}

Statistics were calculated by the $\chi^{2}$ test and the undetermined samples were not included.The cut-off point of the primary tumor was $3 \mathrm{~cm}$ BRCA1, breast cancer 1; TYMS, thymidylate synthetase; STMN1, stathmin 1; TOP2A, topoisomerase II $\alpha$; VEGFR2, vascular endothelial growth factor receptor 2; PDGFR, platelet-derived growth factor receptor; $H E R 2$, human epidermal growth factor receptor 2.

Table IV. Correlations between mRNA levels and clinical characteristics.

\begin{tabular}{|c|c|c|c|c|c|c|c|c|c|}
\hline Characteristic & Statistics & $B R C A l$ & $T Y M S$ & STMN1 & TOP2A & PDGFR & VEGFR2 & KIT & HER2 \\
\hline Gender & $\begin{array}{c}\mathrm{r} \\
\text { P-value }\end{array}$ & $\begin{array}{l}0.179 \\
0.083\end{array}$ & $\begin{array}{l}0.287 \\
0.005\end{array}$ & $\begin{array}{l}0.052 \\
0.618\end{array}$ & $\begin{array}{l}0.245 \\
0.017\end{array}$ & $\begin{array}{r}-0.118 \\
0.256\end{array}$ & $\begin{array}{l}0.052 \\
0.618\end{array}$ & $\begin{array}{r}-0.137 \\
0.187\end{array}$ & $\begin{array}{r}-0.009 \\
0.928\end{array}$ \\
\hline Age (years) & $\begin{array}{c}\mathrm{r} \\
\text { P-value }\end{array}$ & $\begin{array}{l}0.036 \\
0.729\end{array}$ & $\begin{array}{l}0.008 \\
0.940\end{array}$ & $\begin{array}{r}-0.008 \\
0.940\end{array}$ & $\begin{array}{l}0.008 \\
0.940\end{array}$ & $\begin{array}{r}-0.171 \\
0.076\end{array}$ & $\begin{array}{r}-0.008 \\
0.940\end{array}$ & $\begin{array}{l}0.184 \\
0.075\end{array}$ & $\begin{array}{r}-0.080 \\
0.441\end{array}$ \\
\hline Stage & $\begin{array}{c}\mathrm{Q} \\
\text { P-value }\end{array}$ & $\begin{array}{r}-0.056 \\
0.595\end{array}$ & $\begin{array}{l}0.012 \\
0.912\end{array}$ & $\begin{array}{r}-0.061 \\
0.567\end{array}$ & $\begin{array}{l}0.014 \\
0.896\end{array}$ & $\begin{array}{l}0.082 \\
0.442\end{array}$ & $\begin{array}{l}0.276 \\
0.008\end{array}$ & $\begin{array}{r}-0.216 \\
0.040\end{array}$ & $\begin{array}{l}0.140 \\
0.186\end{array}$ \\
\hline Primary tumor & $\underset{\text { P-value }}{\varrho}$ & $\begin{array}{r}-0.036 \\
0.738\end{array}$ & $\begin{array}{l}0.044 \\
0.681\end{array}$ & $\begin{array}{l}0.149 \\
0.164\end{array}$ & $\begin{array}{l}0.151 \\
0.159\end{array}$ & $\begin{array}{r}-0.102 \\
0.340\end{array}$ & $\begin{array}{r}-0.018 \\
0.864\end{array}$ & $\begin{array}{r}-0.161 \\
0.132\end{array}$ & $\begin{array}{r}-0.011 \\
0.921\end{array}$ \\
\hline Lymph nodes & $\underset{\text { P-value }}{\varrho}$ & $\begin{array}{r}-0.023 \\
0.833\end{array}$ & $\begin{array}{l}0.220 \\
0.039\end{array}$ & $\begin{array}{l}0.042 \\
0.693\end{array}$ & $\begin{array}{l}0.197 \\
0.064\end{array}$ & $\begin{array}{l}0.060 \\
0.577\end{array}$ & $\begin{array}{l}0.043 \\
0.687\end{array}$ & $\begin{array}{r}-0.111 \\
0.300\end{array}$ & $\begin{array}{l}0.075 \\
0.483\end{array}$ \\
\hline Distant metastasis & $\begin{array}{c}\mathrm{r} \\
\text { P-value }\end{array}$ & $\begin{array}{l}0.020 \\
0.851\end{array}$ & $\begin{array}{l}0.033 \\
0.761\end{array}$ & $\begin{array}{l}0.020 \\
0.851\end{array}$ & $\begin{array}{l}0.086 \\
0.425\end{array}$ & $\begin{array}{l}0.061 \\
0.572\end{array}$ & $\begin{array}{l}0.285 \\
0.007\end{array}$ & $\begin{array}{r}-0.139 \\
0.195\end{array}$ & $\begin{array}{l}0.217 \\
0.041\end{array}$ \\
\hline Histological type & $\begin{array}{c}\mathrm{r} \\
\text { P-value }\end{array}$ & $\begin{array}{r}-0.419 \\
0.000\end{array}$ & $\begin{array}{r}-0.293 \\
0.004\end{array}$ & $\begin{array}{r}-0.140 \\
0.180\end{array}$ & $\begin{array}{r}-0.247 \\
0.017\end{array}$ & $\begin{array}{l}0.107 \\
0.305\end{array}$ & $\begin{array}{l}0.107 \\
0.305\end{array}$ & $\begin{array}{r}-0.186 \\
0.073\end{array}$ & $\begin{array}{l}0.265 \\
0.010\end{array}$ \\
\hline Differentiation & $\underset{\text { P-value }}{\varrho}$ & $\begin{array}{r}-0.123 \\
0.272\end{array}$ & $\begin{array}{r}-0.264 \\
0.016\end{array}$ & $\begin{array}{r}-0.260 \\
0.018\end{array}$ & $\begin{array}{r}-0.098 \\
0.383\end{array}$ & $\begin{array}{r}-0.069 \\
0.540\end{array}$ & $\begin{array}{l}0.069 \\
0.540\end{array}$ & $\begin{array}{l}0.144 \\
0.197\end{array}$ & $\begin{array}{l}0.115 \\
0.304\end{array}$ \\
\hline Smoking history & $\begin{array}{c}r \\
\text { P-value }\end{array}$ & $\begin{array}{l}0.275 \\
0.009\end{array}$ & $\begin{array}{l}0.254 \\
0.015\end{array}$ & $\begin{array}{l}0.054 \\
0.609\end{array}$ & $\begin{array}{l}0.298 \\
0.004\end{array}$ & $\begin{array}{r}-0.234 \\
0.026\end{array}$ & $\begin{array}{l}0.075 \\
0.482\end{array}$ & $\begin{array}{r}-0.122 \\
0.249\end{array}$ & $\begin{array}{r}-0.031 \\
0.774\end{array}$ \\
\hline
\end{tabular}

The undetermined samples were not included in statistics.The cut-off point of the primary tumor was $3 \mathrm{~cm}$. r, Pearson's product-moment correlation coefficient; $\varrho$, Spearman's rank correlation coefficient; BRCA1, breast cancer 1; TYMS, thymidylate synthetase; STMN1, stathmin 1; TOP2A, topoisomerase II $\alpha ; P D G F R$, platelet-derived growth factor receptor; VEGFR2, vascular endothelial growth factor receptor 2; HER2, human epidermal growth factor receptor 2 . 
and $0.298, \mathrm{P}=0.004$, respectively) and lower expression levels of PDGFR $\beta$ (correlation coefficient: $-0.234, \mathrm{P}=0.026$ ) (Table IV).

\section{Discussion}

In this study, we assessed the mRNA expression levels of 14 genes and investigated the association between gene expression levels and patient characteristics. Of the 9 clinicopathological parameters, six were associated with some of the 14 genes analyzed. Patient gender was associated with TYMS and TOP2A. Clinical stage was associated with VEGFR2, KIT and HER2. There was a weak correlation between a primary tumor size of $\leq 3 \mathrm{~cm}$ and the expression level of $K I T$. The mRNA expression levels of VEGFR2 and HER2 correlated with distant metastasis. BRCA1, TYMS, TOP $2 A$ and HER2 were associated with histological type. Smoking correlated with higher expression levels of BRCA1, TYMS and TOP $2 A$ and lower expression levels of $P D G F R \beta$.

Genes are critical elements in the physiology of cancer, including DNA synthesis, DNA repair and mitosis. Gene expression levels are associated with a response to chemotherapy and targeted therapies $(5,10)$. Traditionally, treatment selection has been based on clinicopathological characteristics and imaging techniques, including computed tomography (CT) or magnetic resonance imaging (MRI).

In previous studies, different mRNA expression levels of genes were associated with different responses to chemotherapy. Olaussen et al observed that the expression level of ERCC1 positively correlated with the response to cisplatin-based and neoadjuvant chemotherapy in NSCLC patients (11). Overexpression of BRCAl was strongly associated with poor survival in NSCLC patients. The mRNA expression levels of BRCAl have been previously associated with differential sensitivity to cisplatin and antimicrotubule drugs (12). The association analysis in this study revealed that patients with adenocarcinoma and smokers were more likely to exhibit higher mRNA expression levels of BRCA1. Therefore, it was hypothesized that smoking patients with adenocarcinoma would not benefit from cisplatin and antimicrotubule therapies. However, larger studies are required to reach a definitive conclusion. A previous study demonstrated that males had higher tumor expression levels of BRCAI compared to females $(\mathrm{P}=0.020)(13)$. We did not observe this difference in the present study, which may be attributed to diversities in race and ethnicity. However, histological type and smoking status may be critical for the treatment of NSCLC.

Lung cancer patients with high expression levels of TYMS mRNA were associated with resistance to fluorouracil-based chemotherapy (14). Ceppi et al reported that Caucasian patients with squamous cell carcinoma exhibited higher TYMS protein expression levels (15). By contrast, another study conducted on Japanese patients demonstrated that tumor cells with higher TYMS expression exhibit higher proliferative activity in NSCLC, especially adenocarcinoma (16). We observed that patients with adenocarcinoma exhibited higher TYMS levels compared to those with squamous cell carcinoma, which was in accordance with the results of the latter study (15). The differrences in the results among studies may be partly due to the racial and ethnic diversities. However, this observation requires elucidation through further large-sample studies. Smokers tended to exhibit higher expression levels of TYMS. This was in accordance with previous studies. Since gene expression levels were found to be associated with clinicopathological characteristics, they may be useful in the selection of NSCLC patients who may benefit from treatment with TYMS-inhibiting agents.

A study demonstrated that low expression levels of RRMI were a favorable indicator for tumor response to gemcitabine, whereas high levels were associated with drug resistance (17). Low expression levels of $T U B B 3$ was a favorable indicator for tumor response to paclitaxel and vinblastine, whereas high levels were associated with drug resistance (18). Overexpression of the EGFR gene was associated with improved response to erlotinib or gefitinib therapy and increased survival in NSCLC patients (19).

STMN1 was characterized as an important regulatory gene of microtubule dynamics, which were comprehensively studied in cancer (20). TOP $2 A$ and HER2 were extensively studied in breast cancer. Previous studies reported that TOP $2 A$ amplification is a marker of sensitivity to anthracyclines $(21,22)$. TOP $2 A$ catalyzes the relaxation of supercoiled DNA and is associated with DNA proliferation and repair $(23,24)$. Previously, a correlation with positive staining for TOP $2 A$ was identified in male adenocarcinoma patients (25). In this study, we observed similar results regarding the association between expression data and clinicopathological characteristics. Furthermore, we found that the expression of TOP $2 A$ was associated with patient smoking status. Since TOP $2 A$ amplification is a marker of sensitivity to anthracyclines, smoking male patients with adenocarcinoma are likely to benefit from anthracycline treatment.

Trastuzumab therapy may be used as a general paradigm for successful targeted therapy: a positive HER 2 status determines the indication for trastuzumab therapy and it is important to use simple, accurate, widely applicable and reproducible methods to screen tumors for gene amplification and/or overexpression (26). Nakamura et al reported that overexpression of HER2 was detected in adenocarcinoma more frequently compared to squamous cell carcinoma in Japanese NSCLC patients (27). Our results demonstrated the opposite; however, these results require further validation. It has been proven that HER 2 expression, particularly in adenocarcinoma, is associated with a poor prognosis $(28,29)$. Studies investigating the expression of HER2 in advanced or metastatic NSCLC patients are required to verify our results, which suggest that the expression of HER2 is associated with metastasis in NSCLC patients. This would be a novel research direction.

KIT is a proto-oncogene encoding KIT protein, a typical type III tyrosine kinase receptor. Clinical observations demonstrated that the positive rate of KIT expression was $87-100 \%$ (30) in gastrointestinal stromal tumors (GISTs) and that high KIT expression levels are associated with the response to imatinib. $P D G F R \beta$ is a single transmembrane glycoprotein and a member of the type III protein tyrosine kinase family, which plays an important role in tumor cell proliferation and angiogenesis (31). Sunitinib and sorafenib are $P D G F R \beta$ tyrosine kinase inhibitors in wide clinical application that directly inhibit tumor cell proliferation and angiogenesis (32). The number of studies focusing on the mRNA expression level of PDGFR $\beta$ in NSCLC, particularly 
on the association between expression and clinicopathological characteristics, is limited. It has been proven that higher levels of PDGFR $\beta$ expression were associated with higher levels of $V E G F$ expression. Therefore, $P D G F R \beta$-overexpressing tumors may be effectively treated with imatinib (33). In this study, we observed that NSCLC patients who were smokers tended to exhibit lower expression levels of $P D G F R \beta$. This finding suggests that $P D G F R \beta$ is a novel biomarker in NSCLC and sets a new direction for future studies.

VEGF is a potent growth factor for endothelial cells. It binds to its receptors, VEGFR-1, VEGFR-2 and, to a lesser extent, VEGFR-3, causing proliferation and migration of endothelial cells, thus promoting angiogenesis (34). Although VEGF overexpression has been directly associated with the process of angiogenesis in NSCLC, the number of studies on clinicopathological characteristics is limited. A previous study focused on the correlation between VEGF levels and the response to treatment with bevacizumab (35).

It has been demonstrated that biomarkers are associated with NSCLC diagnosis and prognosis. However, the association between these genes and specific clinicopathological parameters has not been elucidated. Patient clinicopathological characteristics are critical in the selection of treatment regimens.

Unlike previous testing technology, such as immunohistochemistry (IHC) and fluorescence in situ hybridization (FISH), MBL technology was used in this study. MBL exhibits high sensitivity and parallel detection and is suitable for various sample types. MBL technology is a non-PCR-based technology at the molecular level and is widely used in clinical diagnosis $(36,37)$.

In clinical practice, the elucidation of the association between gene expression profiles and clinicopathological characteristics may aid physicians in selecting patient-suitable treatments. Our findings confirmed an association between expression levels of 14 genes and clinicopathological parameters of NSCLC patients, which increases the possibility of including certain biomarkers in NSCLC diagnostics.

This study investigated the gene expression profiles in Chinese NSCLC patients and systematically analyzed the association of mRNA expression levels with patient characteristics. However, due to the limited sample size and lack of efficacy data, a closer look on the association between gene expression profiles and NSCLC treatment was not feasible. Therefore, additional studies are required, including larger patient samples and clinical outcome data.

In conclusion, this study demonstrated an association between the expression of certain lung cancer-related genes and the clinicopathological parameters of NSCLC patients, which may lead to the inclusion of biomarker detection, in combination with the traditional clinicopathological parameter assessment, in the selection of treatment for NSCLC patients. Furthermore, MBL technology was proven to be a feasible platform for clinical gene tests.

\section{Acknowledgements}

The reagents for this study were provided by SurExam Bio-Tech Co. Ltd., Guangzhou, China. We would like to thank the staff of Beijing Chest Hospital for their assistance.

\section{References}

1. Parkin DM: Global cancer statistics in the year 2000. Lancet Oncol 2: 533-543, 2001.

2. Reardon JT, Vaisman A, Chaney SG and Sancar A: Efficient nucleotide excision repair of cisplatin, oxaliplatin, and Bis-acetoammine-dichloro-cyclohexylamine-platinum (IV) (JM216) platinum intrastrand DNA diadducts. Cancer Res 59: 3968-3971, 1999.

3. Lord RV, Brabender J, Gandara D, et al: Low ERCC1 expression correlates with prolonged survival after cisplatin plus gemcitabine chemotherapy in non-small cell lung cancer. Clin Cancer Res 8: 2286-2291, 2002.

4. Hallett RM, Pond G and Hassell JA: A target based approach identifies genomic predictors of breast cancer patient response to chemotherapy. BMC Med Genomics 5: 16, 2012.

5. Lynch TJ, Bell DW, Sordella R, et al: Activating mutations in the epidermal growth factor receptor underlying responsiveness of non-small-cell lung cancer to gefitinib. N Engl J Med 350: 2129-2139, 2004.

6. De Roock W, Claes B, Bernasconi D, et al: Effects of KRAS BRAF, NRAS, and PIK3CA mutations on the efficacy of cetuximab plus chemotherapy in chemotherapy-refractory metastatic colorectal cancer: a retrospective consortium analysis. Lancet Oncol 11: 753-762, 2010.

7. Joensuu H, Kellokumpu-Lehtinen PL, Bono P, et al: Adjuvant docetaxel or vinorelbine with or without trastuzumab for breast cancer. N Engl J Med 354: 809-820, 2006.

8. Flagella M, Bui S, Zheng Z, et al: A multiplex branched DNA assay for parallel quantitative gene expression profiling. Anal Biochem 352: 50-60, 2006.

9. Ren GJ, Zhao YY, Zhu YJ, et al: Tumor gene mutations and messenger RNA expression: correlation with clinical response to icotinib hydrochloride in non-small cell lung cancer. Chin Med J (Engl) 124: 19-25, 2011

10. Asahina H, Yamazaki K, Kinoshita I, Yokouchi H,Dosaka-Akita H and Nishimura M: Non-responsiveness to gefitinib in a patient with lung adenocarcinoma having rare EGFR mutations S768I and V769L. Lung Cancer 54: 419-422, 2006.

11. Olaussen KA, Dunant A, Fouret P, et al: DNA repair by ERCC1 in non-small-cell lung cancer and cisplatin-based adjuvant chemotherapy. N Engl J Med 355: 983-991, 2006.

12. Rosell R, Skrzypski M, Jassem E, et al: BRCA1: a novel prognostic factor in resected non-small-cell lung cancer. PLoS One 2: e1129, 2007.

13. Joerger M, deJong D, Burylo A, et al: Tubulin, BRCA1, ERCC1, Abraxas, RAP80 mRNA expression, p53/p21 immunohistochemistry and clinical outcome in patients with advanced non small-cell lung cancer receiving first-line platinum-gemcitabine chemotherapy. Lung Cancer 74: 310-317, 2011.

14. Johnston PG, Lenz HJ, Leichman CG, et al: Thymidylate synthase gene and protein expression correlate and are associated with response to 5-fluorouracil in human colorectal and gastric tumors. Cancer Res 55: 1407-1412, 1995.

15. Ceppi P, Volante M, Saviozzi S, et al: Squamous cell carcinoma of the lung compared with other histotypes shows higher messenger RNA and protein levels for thymidylate synthase. Cancer 107: 1589-1596, 2006

16. Nakagawa T, Otake Y, Yanagihara K, et al: Expression of thymidylate synthase is correlated with proliferative activity in non-small cell lung cancer (NSCLC). Lung Cancer 43: 145-149, 2004.

17. Bepler G, Kusmartseva I, Sharma S, et al: RRM1 modulated in vitro and in vivo efficacy of gemcitabine and platinum in non-small-cell lung cancer. J Clin Oncol 24: 4731-4737, 2006.

18. Seve P, Isaac S, Tredan O, et al: Expression of class III \{beta\}tubulin is predictive of patient outcome in patients with non-small cell lung cancer receiving vinorelbine-based chemotherapy. Clin Cancer Res 11: 5481-5486, 2005.

19. Franklin WA, Veve R, Hirsch FR, Helfrich BA and Bunn PA Jr: Epidermal growth factor receptor family in lung cancer and premalignancy. Semin Oncol 29: 3-14, 2002.

20. Jourdain L, Curmi P, Sobel A, Pantaloni D and Carlier MF: Stathmin: a tubulin-sequestering protein which forms a ternary T2S complex with two tubulin molecules. Biochemistry 36 : 10817-10821, 1997.

21. Knoop AS, Knudsen H, Balslev E, et al: Retrospective analysis of topoisomerase IIa amplifications and deletions as predictive markers in primary breast cancer patients randomly assigned to cyclophosphamide, methotrexate, and fluorouracil or cyclophosphamide, epirubicin, and fluorouracil: Danish Breast Cancer Cooperative Group. J Clin Oncol 23: 7483-7490, 2005. 
22. Nielsen KV, Ejlertsen B, Moller S, et al: The value of TOP2A gene copy number variation as a biomarker in breast cancer: Update of DBCG trial 89D. Acta Oncol 47: 725-734, 2008.

23. Lewis SJ, Cherry NM, Niven RM, Barber PV and Povey AC: Associations between smoking, GST genotypes and N7-methylguanine levels in DNA extracted from bronchial lavage cells. Mutat Res 559: 11-18, 2004.

24. Sorensen M, Autrup H, Tjonneland A, Overvad K and Raaschou-Nielsen O: Glutathione S-transferase T1 nullgenotype is associated with an increased risk of lung cancer. Int J Cancer 110: 219-224, 2004.

25. Woenckhaus M, Merk J, Stoehr R, et al: Prognostic value of FHIT, CTNNB1, and MUC1 expression in non-small cell lung cancer. Hum Pathol 39: 126-136, 2008.

26. Barberis M, Pellegrini C, Cannone M, Arizzi C, Coggi G and Bosari S: Quantitative PCR and HER2 testing in breast cancer: a technical and cost-effectiveness analysis. Am J Clin Pathol 129: 563-570, 2008.

27. Nakamura H, Saji H, Ogata A, et al: Correlation between encoded protein overexpression and copy number of the HER2 gene with survival in non-small cell lung cancer. Int J Cancer 103: 61-66, 2003.

28. Cox G, Vyberg M, Melgaard B, Askaa J, Oster A and O'Byrne KJ: Herceptest: HER 2 expression and gene amplification in non-small cell lung cancer. Int J Cancer 92: 480-483, 2001.

29. Nakamura H, Kawasaki N, Taguchi $M$ and Kabasawa K: Association of HER-2 overexpression with prognosis in nonsmall cell lung carcinoma: a metaanalysis. Cancer 103: $1865-1873,2005$

30. Sarlomo-Rikala M, Kovatich AJ, Barusevicius A and Miettinen M: CD117: a sensitive marker for gastrointestinal stromal tumors that is more specific than CD34. Mod Pathol 11: $728-734,1998$.
31. Heinrich MC, Corless CL, Duensing A, et al: PDGFRA activating mutations in gastrointestinal stromal tumors. Science 299: 708-710, 2003.

32. Yamamoto H, Oda Y, Kawaguchi K, et al: c-kit and PDGFRA mutations in extragastrointestinal stromal tumor (gastrointestinal stromal tumor of the soft tissue). Am J Surg Pathol 28: 479-488, 2004

33. Vlahovic G, Rabbani ZN, Herndon JE II, Dewhirst MW and Vujaskovic Z: Treatment with Imatinib in NSCLC is associated with decrease of phosphorylated PDGFR-beta and VEGF expression, decrease in interstitial fluid pressure and improvement of oxygenation. Br J Cancer 95: 1013-1019, 2006.

34. Singhal S, Vachani A, Antin-Ozerkis D, Kaiser LR and Albelda SM: Prognostic implications of cell cycle, apoptosis, and angiogenesis biomarkers in non-small cell lung cancer: a review. Clin Cancer Res 11: 3974-3986, 2005.

35. Yang JC, Haworth L, Sherry RM, et al: A randomized trial of bevacizumab, an anti-vascular endothelial growth factor antibody, for metastatic renal cancer. N Engl J Med 349: 427-434, 2003.

36. Paik S, Kim C and Wolmark N: HER2 status and benefit from adjuvant trastuzumab in breast cancer. N Engl J Med 358: 1409-1411, 2008

37. Zhang YK, Yeager RL and Klaassen CD: Circadian expression profiles of drug-processing genes and transcription factors in mouse liver. Drug Metab Dispos 37: 106-115, 2009. 